Plant Tissue Cult. \& Biotech. 31(2): 173-177, 2021 (December)

DOI: https://doi.org/10.3329/ptcb.v31i2.57345

(C)Bangladesh Assoc. for Plant Tissue Culture \& Biotechnology

\title{
Rooting of the Endemic Brazilian Species Campomanesia pubescens using Biotechnological Techniques
}

\author{
N.A. Campos, G.J. da Silva*1 and R. Paiva \\ Lavras Federal University, Biology Department, Lavras, MG, Brazil \\ Keywords: Conservation, Cerrado, Medicinal plant, Endemic species, Rooting
}

Campomanesia pubescens is a species from the Myrtaceae family, found in the Cerrado, Brazil. Popularly known as gabirobeira (Crispim et al. 2018), it is a fruit shrub tree, and its fruits are consumed in natura as well as manufacturing of pastries and liqueurs. It is widely used for reforestation of degraded areas. Locally it is also used for charcoal and firewood production. Furthermore, their leaves have medicinal properties, most commonly used in folk medicine to combat diarrhea, fever, scurvy and diseases of the urinary tract (Catelan et al. 2018).

Among the micropropagation stages, rooting is usually the step that shows more difficulties, especially in woody species (Singh and Agarwal 2016). Studies suggest that this difficulty is due to the recalcitrance of some metabolites when manipulated in vitro (Moyo et al. 2011). After the rooting step, plants usually need to go through the acclimatization stage which is the phase where the plants coming from in vivo conditions acquires all requirements to grow as a normal plant in the field. In this context, the aim of this study was to establish an in vitro and ex vitro rooting protocol for gabirobeira seedlings.

To establish a rooting and acclimatization protocol we used gabirobeira seedlings maintained in vitro in the Laboratory of Tissue Culture at the Federal University of Lavras, MG, Brazil. Several treatments were performed aimed to root in vitro gabirobeira seedlings, and are described in Table 1.

In all the above described rooting experiments, the culture media were supplemented with $0.9 \mathrm{M}$ sucrose and $0.7 \%$ of agar. The $\mathrm{pH}$ was adjusted to $5.8 \pm 0.1$ before autoclaving at $121^{\circ} \mathrm{C}$ for $20 \mathrm{~min}$. The explants were maintained in a growth chamber at $25 \pm 2^{\circ} \mathrm{C}$ and photoperiod of $16 \mathrm{~h}$ during six weeks, with evaluations every two weeks. The evaluated parameters were: the percentage of rooted shoots, leaf number and sprouting length.

*Author for correspondence: <glacyjaqueline@prof.unipar.br>. ${ }^{1}$ Paranaense University, Molecular Biology Department, Umuarama, PR, Brazil. 
In vitro gabirobeira seedlings that did not show root formation in any of the treatment mentioned above, were used as explant source for ex vitro rooting and acclimatization using the commercial rooting powder Rootone ${ }^{\circledR}$, which has a high concentration of IBA $(3.000 \mathrm{ppm})$. The basal part of the shoots were treated with the powder and then placed in bottles containing vermiculite or Plantmax ${ }^{\circledR}$.

Table 1. Treatments of pre rooting and rooting of all experiments evaluated.

\begin{tabular}{|c|c|c|c|c|c|c|c|c|c|c|}
\hline \multicolumn{2}{|l|}{ Pre rooting } & \multicolumn{9}{|c|}{ Rooting } \\
\hline & & \multirow{2}{*}{$\begin{array}{c}4.4 \mu \mathrm{M} \text { IBA } \\
\text { (6 Weeks) }\end{array}$} & \multicolumn{7}{|c|}{ IBA $\mu \mathrm{M}$} & \multirow{2}{*}{$\begin{array}{l}\text { Growth } \\
\text { chamber } \\
\text { (6 weeks) }\end{array}$} \\
\hline 2 Subcultures & $4.4 \mu \mathrm{M}$ BAP & & 0.0 & 1.5 & 3.0 & 4.5 & 6.0 & 7.5 & 9.0 & \\
\hline & & $4.4 \mu \mathrm{M}$ IAA & \multicolumn{7}{|c|}{$\mathrm{NAA} \mu \mathrm{M}$} & \multirow{2}{*}{$\begin{array}{l}\text { No auxin } \\
\text { (6 weeks) }\end{array}$} \\
\hline 2 Subcultures & $4.4 \mu \mathrm{M}$ BAP & (1 Week) & 0.0 & 1.0 & 5.0 & 10 & 20 & 100 & - & \\
\hline & & $\begin{array}{l}\text { IBA }+1 \mu \mathrm{M} \\
\text { Activated }\end{array}$ & \multicolumn{7}{|c|}{ IBA $\mu \mathrm{M}$} & \multirow{2}{*}{$\begin{array}{l}\text { No auxin } \\
\text { (6 weeks) }\end{array}$} \\
\hline 2 Subcultures & - & (1 week) & 0.0 & 1.0 & 5.0 & 10 & 20 & - & - & \\
\hline & & $\mathrm{IAA}+1 \mu \mathrm{M}$ & \multicolumn{7}{|c|}{ IAA $\mu \mathrm{M}$} & \multirow{2}{*}{$\begin{array}{l}\text { No auxin } \\
\text { (6 weeks) }\end{array}$} \\
\hline 2 Subcultures & - & $\begin{array}{l}\text { Activated } \\
\text { Charcoal } \\
(1 \text { week })\end{array}$ & 0.0 & 1.0 & 5.0 & 10 & 20 & - & - & \\
\hline
\end{tabular}

These plants were kept for 45 days in the containers wrapped with transparent plastic bag as pre-acclimatization in a growth chamber with $25 \pm 2^{\circ} \mathrm{C}$, photon irradiance at $67 \mu \mathrm{m} \mathrm{m}^{-2} \mathrm{~s}^{-1}$ and 16 hours of photoperiod. After these 45 days, the plastic bags were removed and the plants were maintained for another 45 days in the same growth chamber at the same conditions. After these 90 days, were evaluated shoot length, number of leaves, number of roots, primary root length, fresh and dry weight. Were used ten replications per each treatment. The experimental design was completely randomized and the data were analyzed by ANOVA and were submitted to the Scott-Knott test at $0.05 \%$, using the software Statsoft (Weiß 2007).

After 6 weeks in the growth chamber, we verified root formation only at the treatment with IBA. The treatments with 1.5, 4.5 and $6 \mu \mathrm{M}$ of IBA demonstrated higher root average, with $28 \% 53 \%$ and $33 \%$ respectively (Fig. 1).

At the end of 90 days it was observed that 100\% of gabirobeira seedlings transferred to ex vitro conditions survived the acclimatization regardless the used substrate and in $75 \%$ there were root formation (Fig. 2). For the other parameters (shoot length, leaves number, formed roots, main root length, fresh and dry), the different types of substrates tested were not statistically different from each other. Regarding the number of shoots and the length of the shoot, there was an increase by the end of the acclimatization 
period, showing that the seedlings have adapted to the ex vitro environment. As with the previous parameters, the fresh mass and shoot dry mass did not differ statistically.

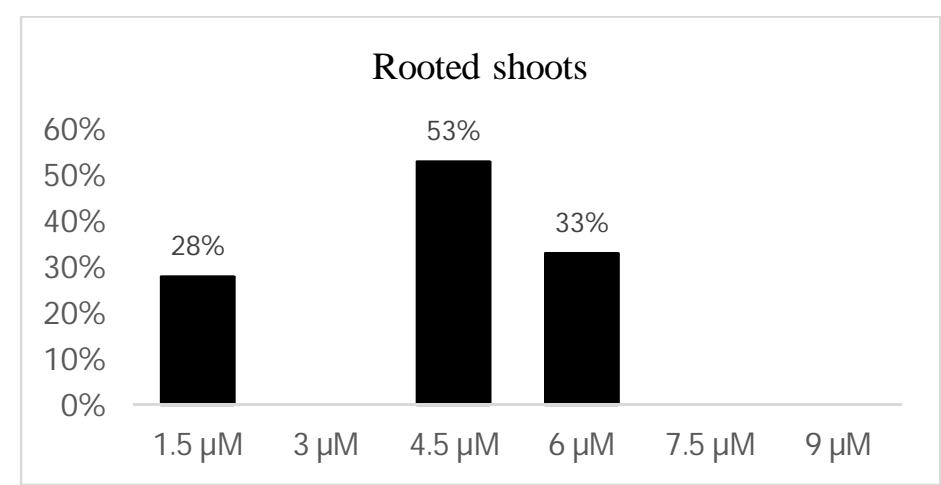

Fig. 1. Percentage of the number of gabirobeira rooted on MS medium with different IBA concentrations after 6 weeks.

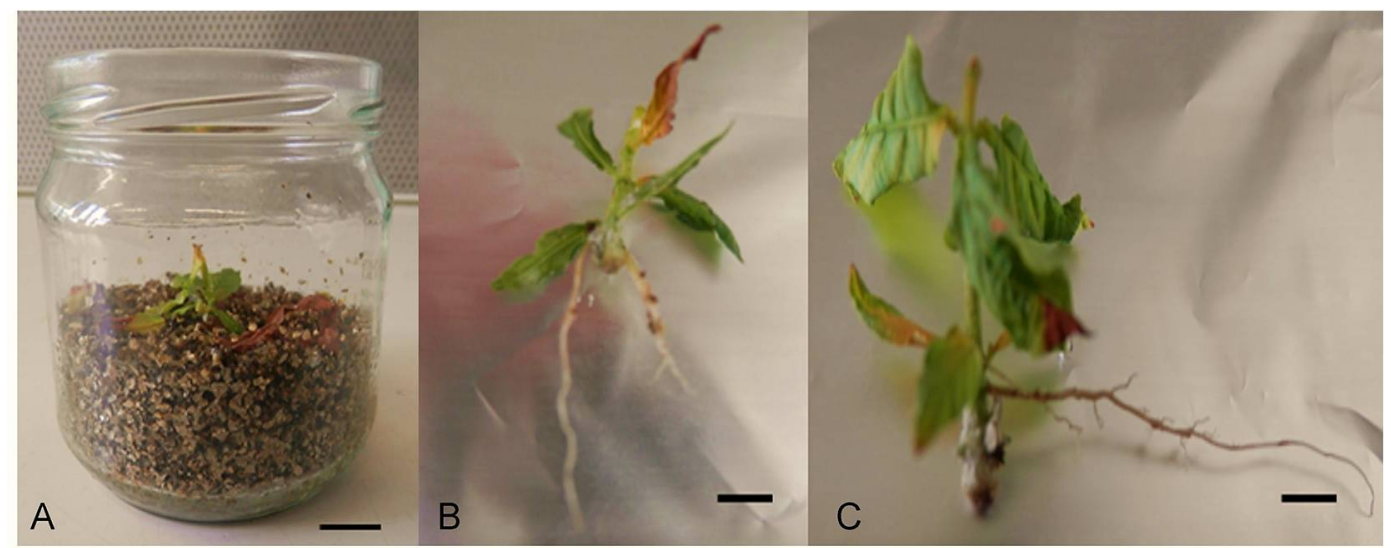

Fig. 2A. Gabiroba after rooting in in vitro condition, pré transferred to ex vitro. B-C. Gabiroba seedling after 90 days of rooting and ready to planting.

The growth regulator IBA has been the most common auxin used for in vitro rooting in different species being successful even with the eucalyptus species (Borges et al. 2012, Scutti and Zanette 2000). In a study with C. xanthocarpa, it was possible to obtain $53 \%$ of rooting from cuttings using WPM medium with IBA (Machado et al. 2020).

There are some studies indicating that the number of in vitro subcultures directly affects the rooting capacity of shoots (Hou et al. 2010). Although most studies report a rooting increase with rising subcultures (Guiyun and Sujuan 2007). The results obtained in C. pubescens show that the subcultures number, negatively influences on in vitro rooting for this species. Practical experience with micropropagation in several cerrado species has shown the negative influence of increasing the number of subcultures. This 
finding can be explained by the fact that subcultures can increase the production of phenolic compounds, especially in woody species, which hinders the in vitro maintenance (George et al. 2008).

According to De Klerke (2002), the problems encountered during the rooting phase in micropropagation, consists one of the constraints to the plants transfer from in vitro to ex vitro. Thus, results such as those obtained in our work is of great interest because the union of acclimatization phase along with the rooting phase may optimize the time and cost for plantlets production.

Pedrotti and Voltolini (2001), investigating the acclimatization and ex vitro rooting in apple rootstock, obtained $64 \%$ rooting in the auxin absence, which is similar to the results found in this study. However, with the use of $1000 \mathrm{mg} /$ of IBA, was observed an increase in the rooting to $84 \%$.

In our study, we were able to establish an in vitro (with IBA) and ex vitro rooting protocol for Gabirobeira. Gabirobeiras can be acclimatized and successfully rooted, with $100 \%$ survival and $75 \%$ rooting using Plantmax ${ }^{\circledR}$ or vermiculite substrate in a period of 90 days.

\section{Acknowledgements}

The authors thank Federal University of Lavras, Posgraduate Program in Plant Biotechnology of Federal University of Lavras, Coordenação de Aperfeiçoamento de Pessoal de Nível Superior (CAPES), Conselho Nacional de Desenvolvimento Científico e Tecnológico $(\mathrm{CNPq})$ and Fundação de Amparo à Pesquisa do Estado de Minas Gerais (FAPEMIG).

\section{References}

Borges SR, Xavier A, Oliveira LS, Lopes AP, Otoni WC, Takahashi EK and Melo LA ((2012)). Estabelecimento in vitro de clones híbridos de Eucalyptus globulus. Cienc Florest 22 :605-616

Catelan, Taline BS, Brum, Camila CS, Heredia-Vieira, Silvia C, Crispim, Bruno A, Grisolia, Alexeia B, Santos, Rafael CS, Cardoso and Claudia AL (2018). Cytotoxicity, Genotoxicity, Antioxidant Potential and Chemical Composition of Leaves of Campomanesia pubescens (Mart. ex DC.) O.Berg. Current Pharmaceutical Biotechnology, Volume 19, Number 5, April 2018, pp. 416-421(6). Bentham Science Publishers . DOI:https:// doi.org/10.2174/1389 ((2010))1666180626102443

Crispim BA, Bajay MM, Vasconcelos AA, Deo TG, Braga RS, Telles MPC, Vieira MC, Carnevali TO, Solórzano JCJ and Grisolia AB (2018). Relationship between Genetic Variability and Land Use and Land Cover in Populations of Campomanesiaadamantium (Myrtaceae). Diversity 2018, 10(4),106; https://doi.org/10.3390/d10040106

De Klerk GJ (2002). Rooting of microcutings: theory and practice. In vitro Cell Dev . Biol. 3: 415422

George EF, Hall MA and De Klerk GJ (2008). Plant propagation by tissue culture - The background. Dordrecht, London 
Guiyun W and Sujuan G (2007). The key factor of tip culture of Castanea mollissima cv. Yanshanhong. Journal of South China Agricultural University 28(Suppl 1): 144-147.

Hou JW, Guo SJ and Wang GY (2010). Effects of in vitro subculture on the physiological characteristics of adventitious root formation in microshoots of Castanea mollissima cv. "yanshanhong". J For Res 21: 155-160

Machado JS, Degenhardt J, Maia FR and Quoirin M (2020). Micropropagation of Campomanesia xanthocarpa O. Berg (Myrtaceae), a medicinal tree from the Brazilian Atlantic Forest. Trees 34(3): 791-799.

Moyo M, Finnie JF and Van Staden J (2011). Recalcitrant effects associated with the development of basal callus-like tissue on caulogenesis and rhizogenesis in Sclerocarya birrea. Plant growth Regulation 63(2): 187-195.

Pedrotti EL and Voltolini JA (2001). Enraizamento ex vitro e aclimatização do porta-enxerto de macieira m.9. Rev Bras Frutic 23: 234-239

Scutti M and Zanette F (2000). Propagação vegetativa da guabirobeira (Campomanesia xanthocarpa berg.) in vitro e por estaquia. Sci Agric 1: 75-82

Singh A and Agarwal PK. (2016). Enhanced micropropagation protocol of ex vitro rooting of a commercially important crop plant Simmondsia chinensis (Link) Schneider. J. For. Sci. 62(3): 107-115. doi:10.17221/80/2015-JFS

Weiß CH (2007). StatSoft, Inc., Tulsa, OK.: STATISTICA, Version 8 Asta 91: 339-3 